\title{
Determinants of Customer Behavioural Responses: A Pilot Study
}

\author{
Ahmed Audu Maiyaki (Corresponding author) \\ College of Business, Universiti Utara Malaysia \\ Block T 008, Kolej Maybank residential hall, Sintok, 06010 Universiti Utara Malaysia \\ Tel: 60-19-555-4831 E-mail: aamaiyaki@yahoo.com \\ Sany Sanuri Mohd Mokhtar \\ Quality Management Centre, Universiti Utara Malaysia, 06010 UUM Sintok, Kedah, Malaysia \\ Tel: 60-13-480-0800Ｅ-mail: sany@uum.edu.my
}

\begin{abstract}
The paper aims at exploring a small sample data on the determinants of customer behavioural responses in the Nigerian retail banking. Hence, instrument validity, reliability and subsequently the data normality were examined through panel of expert and also by analysing small sample data with aid of SPSS software. Results show that the instrument is reliable and the data for preliminary study exhibit reasonable normality. The research explored and validated the instrument of the various antecedents of consumer behavioural responses most of which were hitherto ignored.
\end{abstract}

Keywords: Service quality, Behavioural intention, Actual behaviour, Pilot test, Nigeria

\section{Introduction}

It is believed that the goal of every organisation is to meet the needs and requirements of its stakeholders. Meeting the needs and the requirements of the stakeholders will not only ensure the survival of the organisation but also flourish it. Customer is presumed to be one of the most important stakeholders in any organisation because without him, organisations are not likely to succeed. Hence, customer behavioural intention is one of the main concepts that have been studied in the marketing literature (Ibrahim and Najjar, 2008). It is presumed that the knowledge regarding consumer behaviour will go a long way in ensuring effective marketing policies in favour of customers which will eventually facilitates positive customer attitude towards the organisations, more especially as customer behavioural intention is a strong indication of his actual behaviour (Francis et al., 2004). Similarly, it is important for service providers to understand how the consumers' evaluation of service quality is formed; and that marketing organizations must understand customers' wants/needs and deliver services that will match or exceed the actual experiences with these needs in order to facilitate exchanges Ogungbure, (2009).

Behavioural intentions are signals for the actual purchase and hence it is important that it is monitored (Zeithaml, Berry and Parasuraman, 1996). Behavioural intentions include purchase intention and willingness to pay for premium price and this has critical effects on brand and organisational performance. Keh and Xie (2008) stress that a customer that exhibits both higher purchase intention and willingness to pay a price premium is more likely to stay longer with the service provider and have lower sensitivity to price changes. Behavioural intention is among the most important concepts in marketing literature, perhaps due to its strong relationship with the actual consumer buying behaviour. Morwitz and Schmittlein (1992) posit that several studies have reported a positive correlation between behavioural intentions and the actual customer behaviour. Put differently, if consumers have a high behavioural intention towards a particular product or service then there is likelihood that they will engage into the actual behaviour.

A pilot test is considered to be like "a dress rehearsal" in which a small scale trial of the study is conducted prior to the full-scale study (Gay, Mills and Airasian, 2006). Hence, in this study a pilot test was carried out in order to achieve some objectives. Firstly, the mini study was done to test the validity and reliability of the instrument of the study. Secondly, it aimed at obtaining an insight into the real conditions of the actual study. Thus, this would enable the researcher to anticipate and adjust to potential problems during the full-scale research. Among the major concern of pilot test is the instrument validity and reliability. Validity of the measuring instrument is the extent to which the instrument is measuring what it is suppose to measure and not something else. Reliability of a measure on the other hand, indicates the extent to which an instrument is error free and thus, consistent and stable across time and also across the various items in the scale (Sekaran and Bougie, 2010).

To this end, the paper presents the result of pilot test with regard the influences of service quality, perceived value, corporate image, culture and switching costs on customer behavioural responses in the context of the Nigerian banking industry. 


\section{Methodology}

Given the fact this study is a pilot test of an ongoing project a few samples of customers of Nigerian banks was randomly selected. This is in line with the recommendation by Malhotra (2008) that the sample size for pre-test is normally small, ranging from 15-30 respondents but it be increased substantially if the test involves several stages. Hence, a total of 65 copies of questionnaires were personally distributed and 57 were returned out of which 2 were not properly completed and hence, not considered for analysis. A questionnaire was received after the cut off dateline and thus, not included in the pilot analysis. According to Sekaran and Bougie (2010) the most popular test of inter-item consistency reliability is Cronbach's alpha coefficient. Hence, Cronbach alpha test is employed in this study to measure internal consistency of the instrument. The data was analysed using SPSS version 14 for windows. Before the distribution of the questionnaires, the draft was initially submitted to experts and also to the typical respondent for face and content validity. The whole process was completed within the period of four weeks in the months May/June 2010.

\subsection{Instrumentation and Measurement of Variables}

A structured questionnaire consisting of closed ended multiple choice-questions were employed for the study. Given that most of the items in the questionnaire are targeted to measuring the respondents' perceptions and attitudes, hence, Likert-type scale is considered more appropriate and reliable (Alreck and Settle, 1995; Miller, 1991). The instrument is meant to measure the key variables of the research using a 7-point Likert-type rating scale, ranging from strongly disagree to strongly agree. Selecting the 7-point itemised scale is informed by the recommendations of Krosnick and Fabrigar (1997). They argued that the range of scale between 5 and 7 is established to be more reliable than otherwise; they further emphasise that when measuring a bipolar construct 7-point scale appears to be optimal. This is because a scale with more points enables the respondents to express their stand precisely and comfortably. Similarly, such scale enables the researcher to make more subtle distinction among the attitudes of various individuals regarding a particular object.

A scale with mid-point is adopted based on the comments by Krosnick and Fabrigar (1997) that forcing participants to respond in a particular direction could result to an increase of measurement error. According to Schuman and Presser (1981), associations among attitudes are strengthened when middle options are included into a scale. Similarly, Krosnick and Fabrigar (1997) found that the effects of interviewer bias tend to decrease and data quality tends to increase when a midpoint is included in a scale. In order to give the respondents independence of expressing their feelings, given that some of the target respondents might not be highly educated.

The key variables contained in the study are: perceived service quality (functional), perceived service quality (technical), perceived value, corporate image, switching cost, customer culture, customer behavioural intentions and actual behaviour. All the constructs/variables are uni-dimensional except the service quality, customer cultural values and behavioural intention which are multi-dimensional. In any case, all the latent variables will be measured using multiple items. Accordingly, the questionnaire of this research is made up of eight sections. Section 1: consists of a set of twenty questions that seek to measure the level of service quality (functional) as perceived by the respondents. Section 2: comprises of six questions targeted at measuring technical quality of the bank service. Section 3: is made up of a total of six questions which attempt to measure the extent of corporate image as perceived by the respondents. Section 4: contains six items that are directed to measure the service value as perceived by the respondents. Section 5: contains six items which are meant to assess the level of switching costs/barriers perceived by the respondents. Section 6: is made up of twenty-three questions that seek to measure the respondents' cultural values. Section 7: consists of ten questions that are targeted to evaluate consumer behavioural intentions. Section 8: consists of five questions which are meant to measure the customers' actual behaviour. And finally, section 9: consists of questions about the demographic information of the respondents. Only the relevant items that will be used in answering the research questions are included in the questionnaire. Similarly, sensitive questionnaire are not included in order to elicit high response rate (Sekaran and Bougie, 2010).

\section{Results of Validity and Reliability Tests}

3.1 Content and face validity: ensures that the measure consists of an adequate and representative set of items that tap a particular concept. Put differently, it involves a systematic assessment of the scale's ability to measure what is supposed to measure. Hence, content validity entails consulting a small sample of typical respondents and/or panel of expert to pass judgement on the suitability of the items selected to measure a construct (Hair, Money, Samouel and Page, 2007; Sekaran and Bougie, 2010). Based on the foregoing, a draft of the instrument of this study was distributed to experts in order to get feedback concerning the suitability, content, layout and adequacy of the items that are designed to measure the constructs under investigation. Additionally, some Ph.D. candidates who are familiar with the environmental context of the study were equally contacted to check the clarity of the study 
instrument. To this end, a number of questions were re-worded/re-phrased in order to measure the constructs appropriately and also to be understandable to the potential respondents. It was also observed that some items look the same and therefore, 2 items were recommended to be removed. This process of seeking for expert opinion was completed within two-week period. After taking into consideration of the observation by the experts, then the researcher came up an improved/revised version of the instrument which was ultimately administered for the pilot test.

3.2 Reliability test: Various type of reliability tests are usually employed, however, the common method used by researchers is the internal consistency reliability test (Litwin, 1995). It is the extent to which items "hang together as a set" and are capable of independently measuring the same concept to the extent that the items are correlated with one another. Hence, according to Sekaran and Bougie (2010) the most popular test of inter-item consistency reliability is Cronbach's alpha coefficient. Hence, Cronbach alpha test is employed in this study to measure internal consistency of the instrument. After running the data using SPSS version 14 for windows, it was found that all the measures possess high reliability standard ranging from 0.713 to 0.956 . This is in line with the benchmark that an instrument with coefficient of 0.60 is regarded to have an average reliability while the coefficient of 0.70 and above shows that the instrument has a high reliability standard (Hair, Black, Babin, Anderson, and Tatham, 2006; Nunally, 1967; Sekaran and Bougie, 2010). Similarly, Hair, Money, Samouel, and Page (2007) observe that researchers generally consider that an alpha value of 0.70 as a minimum, however, lower coefficients may be acceptable. Table 1 shows the summary of the reliability results. It could be seen from the table that the result of pilot test indicates that Cronbach's alpha values for the constructs under investigation are all above 0.70. Consequently, given the established benchmark of 0.70 all the constructs are reliable and therefore, there was no need to delete any item.

Furthermore, it is evident from table 2 that the male respondents are more that the female. This is in line with the trend of Nigerian population where male enrolment in school surpasses that of female. Given that this study is conducted in universities, gender distribution is thus, justifiable. Similarly, with respect to educational qualification the respondents with Masters degree are more than any other group indicating that the respondents are relatively educated. With regards to the respondents' age of banking, the statistics show that the respondents banking experience of between 2 and 10 years constitute 80 percent of the sample. This means that majority of the respondents have reasonable experience to commend about the services of their respective banks. In a similar way, the majority of the respondents amounting to 87 percent operate either saving or current accounts which involve high customer contact and consequently, enable him to more accurately evaluate service quality and eventually engage into one behavioural response or the other.

3.3 Data Distribution: Most of the inferential statistical techniques require the fulfilment of normality assumption (Pallant, 2001; Tabacknich \& Fidell, 2007). Normal data is the one that is symmetrical, bell-shape, with the greatest frequency of scores in the middle and smaller distribution towards the extreme ends. Normality can be examined by using the values of skewness and kurtosis. While skewness has to do with symmetary, kurtosis indicates the extent to which the data is peak or flat (Tabacknich \& Fidell, 2007). Based on the values of skewness and kurtosis the data can be described as reasonably normal. For example, the skewness of all the items ranges from -0.014 to -2.849 with only 2 items reaching \pm 2.0 while all others are bellow \pm 2.0 . Similarly, the values for kurtosis ranges from -0.004 to 8.505 well below the threshold of \pm 10 .

\section{Conclusion}

As noted earlier in the paper that the aim of this study is pre-tests the validity and reliability of the instrument of an ongoing project in preparation for the large scale study. Hence, the conclusion of this study is tied to its objective which is mainly statistical in nature at this stage. The managerial implication of the variables under investigation would be fully uncovered after the main study is carried out. The study explored the small scale data that was collected during the pilot test. Both content and face validity were conducted which subsequently led to the rewording of several items and two items were removed on grounds of high similarity with other questions. Furthermore, the inter-item reliability test revealed that all the items were reliable with Cronbach Alpha well above the benchmark of 0.70; thereby no item was deleted. Finally, normality test using skewness and kurtosis shows that the data as a whole is reasonably normal more especially with skewness values not significantly different from zero.

\section{References}

Alreck, P.L. \& Settle, R.B. (1995). The survey research handbook. Second edition, Boston: Irwin

Francis et al. (2004). Constructing questionnaires based on the theory of planned behaviour: A manual for health services researchers. UK: Centre for Health Services Research, University of Newcastle.

Hair, Jr., J. F., Black, W. C., Babin, B. J., Anderson, R. E., \& Tatham, R. L. (2006). Multivariate data analysis $\left(6^{\text {th }}\right.$ ed.). Uppersaddle River, New Jersey: Pearson Education International, Inc. 
Hair, Jr., J. F., Money, A. H., Samouel, P. \& Page, M. (2007). Research methods for business. Chichester: John Willey \& Sons Ltd.

Gay, L. R., Mills, G. E. \& Airasian, P. (2006). Educational research: Competencies for analysis and applications ( $8^{\text {th }}$ ed.). Uppersaddle River, New Jersey: Pearson Education International, Inc.

Ibrahim, H. \& Najjar, F. (2008). Assessing the effects of self-congruity, attitudes and customer satisfaction on customer behavioural intentions in retail environment. Marketing Intelligence \& Planning, 26, 2, 207-227

Keh, H. T., \& Xie, Y., (2008). Corporate reputation and customer behavioural intentions: The roles of trust, identification and commitment. Industrial Marketing Management, doi:10.1016/j.indmarman.

Krosnick, J.A. \& Fabrigar, L.R. (1997). Designing rating scales for effective measurement in surveys. In L. Lyberg, P. Biemer, M. Collins, E. De Leeuw, C. Dippo, N. Schwarz and D.Trewin (Eds.), Survey measurement and process quality. New York: John Wiley \& Sons, Inc.

Litwin, M.S. (1995). How to measure survey reliability and validity. Thousand Oaks, California: Sage Publication Malhotra, N.K. (2008). Essentials of marketing: An applied orientation (2 ${ }^{\text {nd }}$ ed.). Australia: Pearson Education

Miller, C.D. (1991). Handbook of research design and social measurement. Newbury Park, California: Sage publications

Morwitz, V.G. \& Schmittlein, D. (1992). Using segmentation to improve sales forecasts based on purchase intention: Which intenders actually buy? Journal of Marketing Research 29, 391-405.

Ogungbure, A. T. (2009). An attributional approach to the formation of recovery expectations in the internet-based service encounters after service failure and recovery. Unpublished doctoral dissertation, Nova Southeastern University

Pallant, J. (2001). SPSS survival manual: A step by step guide to dada analysis using SPSS for windows. Maidenhead, UK: Open University Press

Schuman, H. \& Presser, S. (1981). Questions and answers in attitude surveys. New York: Academic Press

Sekaran, U. \& Bougie, R. (2010). Research methods for business: A skill building approach (5 ${ }^{\text {th }}$ ed.). Chichester: John Willey \& Sons Ltd

Tabachnick, B.G. \& Fidell, L.S. (2007). Using multivariate statistics ( $5^{\text {th }}$ ed.). Boston: Pearson Education Inc.

Zeithaml, V.A., Berry, L.L. \& Parasuraman, A. (1996). The behavioural consequences of service quality. Journal of Marketing, 60, 31-46.

Table 1. Summary of Reliability Test Using SPSS version 14 for windows

\begin{tabular}{|c|c|c|c|}
\hline Construct & Dimensions & No. of items & Cronbach's Alpha \\
\hline \multirow[t]{6}{*}{ Functional quality } & Five & 20 & 0.956 \\
\hline & Tangibility & 4 & 0.886 \\
\hline & Reliability & 4 & 0.831 \\
\hline & Assurance & 4 & 0.884 \\
\hline & Responsiveness & 4 & 0.869 \\
\hline & Empathy & 4 & 0.799 \\
\hline Technical quality & & 6 & 0.935 \\
\hline Corporate image & & 6 & 0.947 \\
\hline Perceived value & & 6 & 0.918 \\
\hline Switching costs & & 6 & 0.884 \\
\hline \multirow[t]{6}{*}{ Culture } & Five & 23 & 0.882 \\
\hline & Individualism/ collectivism & 4 & 0.748 \\
\hline & Power distance & 5 & 0.877 \\
\hline & Masculinity/Feminity & 4 & 0.858 \\
\hline & Uncertainty/Avoidance & 5 & 0.876 \\
\hline & Long-term orientation & 5 & 0.713 \\
\hline Behavioural intention & & 10 & 0.861 \\
\hline Actual behaviour & & 5 & 0.828 \\
\hline Total & & 82 & \\
\hline
\end{tabular}

Description for the above table. 
Table 2. Demography of respondents

\begin{tabular}{|c|c|c|c|}
\hline$S / N$ & Items & Frequency (N) & Percentage (\%) \\
\hline 1 & $\begin{array}{l}\text { Gender } \\
\text { Male } \\
\text { female }\end{array}$ & $\begin{array}{l}38 \\
17 \\
\end{array}$ & $\begin{array}{l}69.1 \\
30.9 \\
\end{array}$ \\
\hline 2 & $\begin{array}{l}\text { Age } \\
18-25 \text { years } \\
26-35 \text { years } \\
36-45 \text { years } \\
46-55 \text { years }\end{array}$ & $\begin{array}{l}14 \\
25 \\
15 \\
1\end{array}$ & $\begin{array}{l}25.5 \\
45.5 \\
27.2 \\
1.8\end{array}$ \\
\hline 3 & $\begin{array}{l}\text { Marital status } \\
\text { Single } \\
\text { Married } \\
\end{array}$ & $\begin{array}{l}25 \\
30 \\
\end{array}$ & $\begin{array}{l}45.5 \\
54.5 \\
\end{array}$ \\
\hline 4 & $\begin{array}{l}\text { Educational qualification } \\
\text { GCE/WAEC/NECO or equivalent } \\
\text { OND/NCE or equivalent } \\
\text { HND/B.Sc. or equivalent } \\
\text { M.Sc./M.A/MBA or equivalent }\end{array}$ & $\begin{array}{l}10 \\
14 \\
10 \\
21\end{array}$ & $\begin{array}{l}18.2 \\
25.5 \\
18.2 \\
38.2 \\
\end{array}$ \\
\hline 5 & $\begin{array}{l}\text { Ethnic group } \\
\text { Hausa/Fulani } \\
\text { Yoruba } \\
\text { Igbo } \\
\text { Others } \\
\end{array}$ & $\begin{array}{l}11 \\
34 \\
5 \\
5 \\
\end{array}$ & $\begin{array}{l}20 \\
61.8 \\
9.1 \\
9.1 \\
\end{array}$ \\
\hline 6 & $\begin{array}{l}\text { Banking duration } \\
\text { Less than } 1 \text { year } \\
\text { Between } 2 \text { and } 5 \text { years } \\
\text { Between } 6 \text { and } 10 \text { years } \\
\text { Between } 11 \text { and } 20 \text { years } \\
\text { More than } 20 \text { years } \\
\end{array}$ & $\begin{array}{l}6 \\
29 \\
15 \\
4 \\
1\end{array}$ & $\begin{array}{l}10.9 \\
52.7 \\
27.3 \\
7.3 \\
1.8 \\
\end{array}$ \\
\hline 7 & $\begin{array}{l}\text { Account type } \\
\text { Savings account } \\
\text { Current account } \\
\text { Deposit account } \\
\text { Domiciliary account } \\
\end{array}$ & $\begin{array}{l}29 \\
19 \\
3 \\
4\end{array}$ & $\begin{array}{l}57.2 \\
34.5 \\
5.5 \\
7.3 \\
\end{array}$ \\
\hline
\end{tabular}

